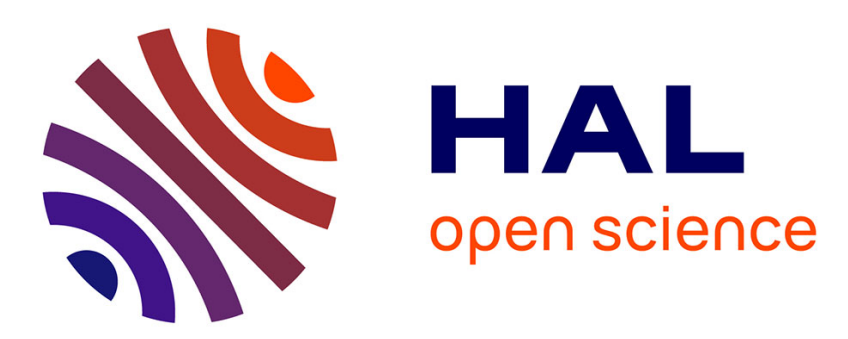

\title{
Reversible splenial lesion syndrome during venoarterial extracorporeal membrane oxygenation
}

\author{
Loïc Le Guennec, Matthieu Schmidt, Alain Combes, Charles-Edouard Luyt
}

\section{To cite this version:}

Loïc Le Guennec, Matthieu Schmidt, Alain Combes, Charles-Edouard Luyt. Reversible splenial lesion syndrome during venoarterial extracorporeal membrane oxygenation. Intensive Care Medicine, 2019, 45 (7), pp.1019-1020. 10.1007/s00134-018-5394-3 . hal-02986110

\section{HAL Id: hal-02986110 https://hal.sorbonne-universite.fr/hal-02986110}

Submitted on 2 Nov 2020

HAL is a multi-disciplinary open access archive for the deposit and dissemination of scientific research documents, whether they are published or not. The documents may come from teaching and research institutions in France or abroad, or from public or private research centers.
L'archive ouverte pluridisciplinaire HAL, est destinée au dépôt et à la diffusion de documents scientifiques de niveau recherche, publiés ou non, émanant des établissements d'enseignement et de recherche français ou étrangers, des laboratoires publics ou privés. 


\section{Reversible splenial lesion syndrome during venoarterial-extracorporeal}

\section{membrane oxygenation}

Loïc Le Guennec ${ }^{1,2}$, MD ; Matthieu Schmidt1,2 MD,PhD; Alain Combes ${ }^{1,2}$, MD,PhD and Charles-Edouard Luyt ${ }^{1,2}$ MD,PhD

${ }^{1}$ Service de Réanimation, Institut de Cardiologie, Groupe Hospitalier Pitié-Salpêtrière, Assistance Publique-Hôpitaux de Paris, Paris, France; ${ }^{2}$ Sorbonne Universités, UPMC Université Paris 06, INSERM, UMRS_1166-ICAN Institute of Cardiometabolism and Nutrition, Paris, France;

Corresponding author: Loic Le Guennec, MD, Service de Réanimation, ICAN, Groupe Hospitalier Pitié-Salpêtrière, 47-83, boulevard de l'Hôpital, 75651 Paris Cedex 13, France.

Tel: +33 (0)1 421638 16; Fax: +33 (0)1 421638 17; Email: loic.leguennec@aphp.fr

Word count: 118

Figure: 2 
A 29-year-old woman with a sickle cell disease was admitted for severe vaso-occlusive crisis, acute respiratory distress syndrome and acute pulmonary hypertension refractory to conventionnal therapy. She was placed on venoarterial extracorporeal membrane oxygenation (va-ECMO) and remained comatose after ECMO removal. Brain magnetic resonnance imaging found a cytotoxic edema within the splenium callosum and microbleeds (Fig. 1), and after few days, patient neurological condition improved, with regression of the splenial lesion (Fig. 2). Diagnosis of reversible splenial lesion syndrome (RESLES) associated with ECMO was finally retained. RESLES is a rare cause of unexplained coma, associated with favorable neurological outcome. On the basis of our research, this is the first description of RESLES association with ECMO support in literature. 


\section{Figure Legends}

\section{Figure 1:}

Magnetic resonance imaging after extracorporeal membrane oxygenation withdrawal : (A) Axial fluid-attenuated inversion recovery (FLAIR) imaging showing hypersignal involving the splenium of the corpus callosum ; (B) Diffusion-weighted imaging (DWI) showing hyperintensity involving the splenium of the corpus callosum with low apparent diffusion coefficient ; (ADC) (C) Susceptibility weighted magnetic resonance sequences (SWAN) showing widespread subcortical microbleeds in the white matter, predominating in subcortical U fibers.

\section{Figure 2:}

Magnetic resonance imaging 1 month later:

(A) Axial fluid-attenuated inversion recovery (FLAIR) imaging showing total regression of the previous splenial lesion; (B) Diffusion-weighted imaging (DWI) is normal (C) Susceptibility weighted magnetic resonance sequences (SWAN) showing partial microbleeds resorption. 


\section{Declarations}

\section{Ethics approval and consent to participate}

In accordance with the ethical standards of our hospital's Institutional Review Board (Committee for the Protection of Human Subjects) and current French law, informed consent for demographic, physiological and hospital-outcome data analyses was not obtained because this observational study did not modify existing diagnostic or therapeutic strategies. Nonetheless, patients and/or relatives were informed about the anonymous data collection and told that they could decline inclusion. This database is registered at the Commission Nationale l'Informatique et des Libertés (CNIL, registration no. 1950673).

\section{Consent for publication}

Not applicable

Funding: None

Conflicts of interest: Alain Combes has received fees from Maquet. The other authors have no conflicts of interest to declare in relationship with this manuscript.

Author Contributions: Author Contributions: Loïc Le Guennec and Charles-Edouard Luyt, wrote the manuscript. Matthieu Schmidt, Nicolas Bréchot, Guillaume Hékimian, Guillaume Lebreton, Ania Nieszkowska, Pascal Leprince and, Alain Combes critically reviewed the manuscript. 